for the Spiritual in the Realm of Science". The spiritual in this case is not to be identified with the 'spiritual' which Sir Oliver has so closely and patiently pursued in the purely human sphere. $\mathrm{H}_{\Theta}$ has, as always, a word on this topic, and pleads for the open mind, a plea which every fair-minded person will be willing to support. But he goes on to speakand it is the burden of his speech-of the need of admitting a spiritual explanation of the phenomena of the world as a whole.

\section{Spiritual Elements in Science}

SIr OlIver is arguing throughout with those who maintain the strictly scientific or agnostic attitude, and in doing so he postulates what he calls "spiritual elements" or a "spiritual influence", which at the end of his discourse he weaves into "the one Reality which gives meaning to the existence of the whole material world ... and illuminates the whole universe with Immortal Love ". It is a fine passage, which takes us back to the triumphant finale of Dante's "Paradiso "- -but one is bound to recognise that it is a supreme act.of faith, an apotheosis of the Unknown rather than any. extension of the scientific outlook. Science, qua science, will agree with Sir Oliver that the mere fact of the human mind attaining the power of prediction-forming, that is, scientific laws-proves that the universe, as presented to us, acts in an orderly or rational way. It will also agree with him that the progress of the human mind exhibits the development of truth, beauty, and love. But when he proceeds to evoke and apply these conceptions-as he frankly does-at any point in the story of evolution where scientific knowledge fails, one sees a danger and remembers the famous Hippocratic diagnosis of the sacred disease the "sacred disease' was that of which men had not yet dis. covered the natural cause. Our religion should inspire and encourage, but, above all, it must not relieve us of the primary duty of following the truth into its most remote retreat.

\section{World Agricultural Policy}

THE general assembly of the International Commission of Agriculture, which met at Lausanne on July 21-22, was attended by delegates from sixteen countries and thirty-five national agricultural organisations, and a statement has been issued on world agricultural policy. It was emphasised that the world agricultural crisis is due to the fact that production and the increased means of securing production have outstripped both present consumption possibilities and population increases, while purchasing power has meanwhile declined. The Commission therefore considers that a judicious organisation of production and exchange will constitute one of the most effective means for fighting the agricultural crisis and establishing the prosperity of nations on a new basis. The first step would be to substitute orderly marketing, through the agency of associated bodies or by means of systematic State-controlled quota import arrangements, for the present unregulated offers of large quantities of commodities on world markets. Simul- taneously, all means of stimulating consumption in general will have to be considered. Efforts will have to be made to improve and regularise quality and to cheapen retail sale. An appropriate wages policy will have to be adopted which, while allowing of a decrease in the number of the unemployed, will take account of national purchasing power. The question of new markets should also be studied, and, for the time being, also that of the export of existing surpluses to countries where the populations are suffering from underfeeding or famine. Further, an increased consumption of products of animal origin would absorb a larger portion of the surplus of vegetable products, which would be transformed into milk and meat. Finally, building should be encouraged by all suitable means. The International Commission of Agriculture recommends agriculturists to support the work of international collaboration, to associate themselves with efforts which aim at the maintenance of peace, at guaranteeing the security of property, and at drawing closer the bond which unites economic groups and nations in a common interest.

\section{International Scientific Centres in Paris}

LA Maison du Savant, which is to be built in Paris, will be a well-appointed meeting-place for French and foreign men of science, if the present plans come to fruition. Lecture rooms, restaurant, winter-garden, and other amenities will be at the disposal of members and visitors. In addition, it will possess an extensive office of information which will study projects for the erection of up-to-date laboratories and research institutions, and organise congresses, exhibitions, conferences, and all publicity necessary to attain the organisation's aims. An illustrated periodical will also be published eventually, to inform the public of the general progress of science. Other activities include a benevolent fund and the provision of scholarships. The Maison du Savant is under the patronage of M. Lebrun, President of the French Republic; it has received government support, and its honorary committee consists of a distinguished group of academicians, including MM. le Chatelier, Charcot, le duc de Broglie, Richet, etc. Its founder and president is M. Georges Lecuyer, president of the International Union of Decorative Arts, and its active director is M. Jean de Chappedelaine. The organisation hopes to raise fifty million francs in the near future for its extensive programme. Through the official support of the Chamber of Deputies and the Municipality of Paris, a beginning has been made with convenient office rooms at 5 Avenue de l'Opéra, Paris.

"LA Maison Internationale de la Science" is a project put forward on the occasion of the Colonial Exhibition of last year, during an international congress of men of science and research workers, for the furtherance of their interests. Its temporary headquarters are at the Institut Marey, Avenue GordonBennett, Paris. It has not been very active, owing to the absence of its director, M. Pélissier, on a government mission to the island of Réunion ; in all probability it will join forces with the Maison du Savant. "Le Foyer International Universitaire" is a centre

No. 3275 , VoL. 130] 